\title{
IS THERE AN INTERNATIONAL CRIMINAL LAW?*
}

\author{
L.C. GREEN**
}

In this pragmatic discussion of international criminal law, the author provides both an analytic and historical overview of the jurisprudence. The roles of treaties, conventions, and the United Nations are presented as the relationship between international and domestic criminal law is explored. In this process, the author distinguishes international legal posturing from bona fide attempts to create an international criminal law.

Whenever there is an incident of a somewhat atrocious character that strikes the headlines of the international press and creates a sense of outrage in the public mind, there tends to be an outcry for something to be done on the international level whereby punishment might be meted out to the offender. This leads people to call for an international criminal law together with a tribunal to administer it. At the same time, there are always demands for action by the United Nations. It tends to be forgotten that the United Nations is not a world parliament, nor for that matter is it a body that deals with law as such. It is rather a standing diplomatic conference to which the member states send their delegates to debate political issues, from a political point of view, in accordance with the political instructions they receive from those member states, in order to reach a political decision. Even when there is some outrageous atrocity committed, there are bound to be some members of the United Nations which will sympathise with the offender, will point out that the end he was seeking was sufficiently righteous to justify his means, and that, even if one disagrees with the means, it should not be condemned.

What then is meant by international criminal law? First, some reference must be made to the nature of international law and the problems that fall within its competence. International law may be defined as that system of laws and regulations which those who operate on the international scene - be they states or international organizations like the United Nations - recognize as being necessary for their orderly conduct, and which they recognize as being binding upon themselves in order to achieve that orderly conduct. ${ }^{1}$ That is to say, it is the system of rules which apply as between such entities and will only have effect if the interests of more than one such entity are affected. This means that an act committed within the territory of a single state and in no way affecting the interests of another state, whether those interests be material or the person of its nationals, will normally be of no concern to international law, however atrocious the act may in fact be.

It also has to be pointed that there is at present no international criminal court which could try an offender accused of having committed an international crime, however that be defined, and even if we had such a court it would be impossible to bring before it a state alleged to be itself responsible for the commission of such an abominable act. An example of the type of act one has in mind is genocide. This is defined in the Genocide

* Lecture delivered in the "University Professor Series" at the University of Alberta, on 17 February 1983.

** LL.B., LL.D., F.R.S.C., University Professor, University of Alberta.

1. See Green, Law and Society (1975) Ch. IV - 'Is International Law Law?' 
Convention of $1948^{2}$, to which Canada is a party, as an act "committed with intent to destroy, in whole or in part, a national, ethnic, racial or religious group, as such", and the parties have undertaken to amend their criminal law accordingly and to provide effective penalties. A policy of this kind can only be instituted with the complicity, collusion or tolerance of a public authority. Despite the activities of Jack the Ripper or M. Landru, this is not the type of offence likely to be committed by private enterprise. The Convention provides that until such time as there is established an international tribunal with criminal competence to try such an offence, those committing it or responsible for its commission shall be tried before the courts of the territory in which it has been committed. It is somewhat difficult to envisage the president of a state instructing his chief justice to institute proceedings for this offence against the commander in chief of the national armed forces. In so far as a trial is concerned, it is perhaps worth mentioning that Canada has amended the Criminal Code ${ }^{3}$ to render genocide a crime under national law. According to this amendment, "genocide' means any of the following acts committed with intent to destroy in whole or in part any identifiable [color, race, religion or ethnic] group, namely (a) killing members of the group, or (b) deliberately inflicting on the group conditions of life calculated to bring about its physical destruction." Of course, those who actually kill any member of such a group will be guilty of murder, so that there seemed little need to introduce such an amendment to the Criminal Code. For those who advocate or promote genocide, and these may well be governmental officials, the penalty envisaged is a maximum of five years imprisonment, probably not the 'effective' penalty envisaged in the Convention.

This reference to the problem of prosecuting genocide is illustrative of the difficulties confronting efforts to establish any international criminal tribunal. In the first place, states, that is to say governments, are unwilling to surrender jurisdiction over their own nationals, even if they only suggest that this is because they do not trust the impartiality and integrity of foreign judges. Second, they fear the attempt that may be made to bring heads of state or of governments to trial. At present, the normal basis for the exercise of criminal jurisdiction by a state is that the offence was committed within its territory, regardless of the nationality of the offender or of the victim. In exceptional cases, touching the security of the state ${ }^{4}$ or its conceptions of public policy as expressed in such offences as bigamy ${ }^{5}$, the state will exercise jurisdiction over crimes committed by nationals abroad. Even more rarely, on the ground of what is sometimes described as functional protection, a state will exercise criminal jurisdiction in respect of grave offences committed against its nationals, regardless of the locality of the offence or the nationality of the offender ${ }^{6}$.

2. 78 U.N.T.S. 277.

3. S. 281.1 .

4. See, e.g., $R$. v. Casement [1917] 1 K.B. 98. Such jurisdiction will even extend to an alien wrongly in possession of a passport and thus apparently enjoying protection: Joyce $v$. D.P.P. [1946] A.C. 347.

5. See, e.g., Trial of Earl Russell [1901] A.C. 446.

6. See, e.g., Eichmann v. Att. Gen. Israel (1962) 36 I.L.R. 277; see also Green, 'The Maxim Nullum Crimen Sine Lege and the Eichmann Trial' (1962) 38 Brit. Y.B. Int'l L. 457, 463-8. 
There are, however, certain offences which are considered so grave and so inimical to the maintenance of world order that states claim the right to exercise jurisdiction in respect thereof, regardless of the nationality of the offender or his victim or the place in which the act in question has been committed. Perhaps the most famous of such offences is piracy, the perpetrators of which are described as hostes humani generis ${ }^{7}$ - enemies of all mankind. The basis for such jurisdiction is the authority granted by international law. In this instance, therefore, all that is meant by international criminal law is that states are given authority to try offenders even though, under the normal rules relating to criminal jurisdiction, this would not have been the case. Moreover, international law defines the offence as piracy jure gentium, and if states seek to extend or change that definition by their own criminal law, any deviations from it may only be exercised against their own nationals ${ }^{8}$. This offence and the right to exercise jurisdiction in respect thereof have evolved through custom and state practice, resulting from the conviction of maritime states that to allow such activities to go unpunished would result in the frustration of all international commerce and eventually the freedom of the seas itself. The concept of piracy as a crime has become so generally accepted that when in 1971 a Malaysian judge sentenced the captain of a Chinese junk for piracy in the South China Seas, his entire judgment consisted of the statement, "You have been found guilty of piracy; you know piracy is a crime. Fourteen years"9. Although piracy jure gentium has developed by practice, the United Nations Conference on the Law of the Sea in 1958 felt it necessary to include a definition of the offence in the Convention on the High Seas, extending the offence to acts against aircraft ${ }^{10}$, and confirmed the duty of all states to "cooperate to the fullest possible extent in the repression of piracy on the high seas ${ }^{11}$ [, recognizing that] the courts of the State which carried out the seizure may decide upon the penalties to be imposed." 12

In the past, many piratical acts were directed to the capture of slaves and states interested in maritime commerce, particularly Great Britain $^{13}$, sought to have slave-trading condemned in the same way as piracy, as a criminal act contrary to international law. British attempts to control the trade, partly motivated by fears of economic competition and partly by Quaker idealism, met some support from the Treaty of Vienna ${ }^{14}$ terminating the Napoleonic Wars, but were frustrated somewhat by the active opposition of the United States ${ }^{15}$. However, by the Brussels General Act for the Suppression of the Slave Trade, ${ }^{16}$ effective international control was established at least for Africa and the seas

7. See In re Piracy Jure Gentium [1934] A.C. 586.

8. See The Le Louis (1817) 2 Dods. 210, 165 E.R. 1464.

9. Personal letter from judge to the writer.

10. 450 U.N.T.S. 11, Art. 15, not ratified by Canada.

11. Art. 14.

12. Art. 19.

13. See, e.g., The Creole (1841) 4 Moore, Int. Arb., 4375; 2 McNair, Int'l Law Opinions 85; see also, Ward, The Royal Navy and the Slavers: The Suppression of the Atlantic Slave Trade (1969).

14. (1815) Additional Article, 65 C. T.S. 257.

15. See The Enterprise and Others (1831-1840) 4 Moore, supra n. 13 at 4349, 4374.

16. (1890) 173 C.T.S. 294. 
around Arabia. Further steps were taken under the auspices of the League of Nations ${ }^{17}$, and in 1956 the United Nations sponsored the Supplementary Convention on the Abolition of Slavery, the Slave Trade and Institutions and Practices Similar to Slavery ${ }^{18}$. While it is true that the slave trade is virtually at an end, all that the Convention provides is that the Parties shall make slave-trading a criminal offence subject to "very severe penalties [and] exchange information in order to ensure the practical coordination of the measures taken by them in combatting the slave trade and shall inform each other of every case of the slave trade. . . which comes to their notice" ${ }^{19}$. There is no attempt to set up an international tribunal to try slave traders or to extend the jurisdiction of the parties to the Convention so as to enable them to prosecute non-nationals or seize ships flying flags other than their own.

The first modern attempt to introduce anything in the nature of international punishment arose after the capture of Napoleon with his exile, first to Elba and then to St. Helena. But this was done by executive and not judicial action. After the First World War, however, the principal Allied and Associated Powers sought to deal judicially with the former Emperor of Germany. By Article 227 of the Treaty of Versailles: ${ }^{20}$

The Allied and Associated Powers publicly arraign William II of Hohenzollern, formerly German Emperor, for a supreme offence against international morality and the sanctity of treaties.

A special tribunal will be constituted to try the accused, thereby assuring him the guarantees essential to the right of defence. It will be composed of five judges, one appointed by each of the following Powers: namely, the United States of America, Great Britain, France, Italy and Japan. In its decision the tribunal will be guided by the highest motives of international policy, with a view to vindicating the solemn obligations of international undertakings and the validity of international morality. It will be its duty to fix the punishment which it considers should be imposed.

It is interesting to note that there is not one reference to criminality or international law as such, although breach of treaty is described as an offence. It should also be noticed that the tribunal was not enjoined to apply international law, but to be guided by "the highest motives of international policy." Nothing came of this because of the Dutch refusal to surrender the Emperor for trial. More important from the point of view of international criminal law was Article 228 whereby the German Government recognized the right of the Allies "to bring before military tribunals persons accused of having committed acts in violation of the laws and customs of war." While Germany subsequently refused to surrender such persons, she did in fact try a number who were accused of such offences, although the penalties imposed were hardly severe ${ }^{21}$. The basis for such trials was customary law and not any written document, although the Regulations attached to Hague Convention IV concerning the Rules and Customs of War on Land of $1907^{22}$ did indicate the conduct during war which might be considered as permitted and that which was forbidden. By

17. 1926, as amended 1953, 212 U.N.T.S. 17.

18. 266 U.N.T.S. 3 - Canada became a party in 1963.

19. Art. 3.

20. (1919) 100 B.F.S.P. 298; (1919) 13 Am. J. Int'l L, Supp.

21. See Mullins, The Leipzig Trials (1921). The best-known of these are The Dover Castle and The Llandovery Castle: see Cameron, The Peleus Trial (1948) App. X, IX, resp.

22. See Schindler and Toman, The Laws of Armed Conflicts (1973) 57. 
the Geneva Conventions of $1929^{23}$ similar rules were laid down with regard to the treatment of prisoners of war and the wounded and sick, and although it was clearly indicated that some acts would be in breach of these rules, no provision was made for their trial. Instead, the post-1945 trials, other than those conducted by the International Military Tribunals at Nuremberg and Tokyo, were organized in accordance with the national systems of military or criminal law of the various countries concerned ${ }^{24}$, with the accused charged with offences defined by the international law regulating armed conflict. In the case of Canada, this may be seen from the terms of the War Crimes Act ${ }^{25}$, which defines a war crime as "a violation of the laws or usages of war committed during any war in which Canada has been or may be engaged after the ninth day of September, 1939"26. It should be pointed out at this stage that while it would appear that the law concerning war crimes only applies vis-à-vis an enemy, this is not really the case. In so far as members of one's own forces are concerned, there is no need for international law to extend the right to exercise jurisdiction as is the case with an alien committing his war crime against a non-national while abroad. The members of one's own forces are liable to trial in accordance with the national criminal or military law, as was the case with Lieutenant Calley ${ }^{27}$, even though that law may describe the offence in question as one against the laws and customs of war.

As for the International Military tribunals at Nuremberg and Tokyo, these were special ad hoc courts established by or on behalf of the United Nations - the name of the wartime alliance - to try those whose crimes were so widespread that they had no specific geographic location. The only criticism that can really be made of these trials is that their constituent instruments ${ }^{28}$ described aggressive war, that is to say war in breach of treaty, as an international crime. The other offences over which the Tribunals were afforded jurisdiction were in fact war crimes in the traditional sense, even though some were described as crimes against humanity. By virtue of their acceptance of the United Nations General Assembly Resolution Affirming the Principles of International Law Recognized by the Charter of the Nuremberg Tribunal, ${ }^{29}$ the members of the United Nations have accepted that those principles, including that which affirms the criminality of aggressive war, are declaratory of the customary law regarding crimes against the law of armed conflict.

23. Id. at 247 (Wounded and Sick), 262 (Prisoners of War); ratified by Canada 1933.

24. See United Nations War Crimes Commission, Law Reports of Trials of War Criminals, 15 vols., and History of the U.N. War Crimes Commission and the Development of the Laws of War (1948).

25. $10 \mathrm{Geo}$. VI, c. 73; see Green, "Canadian Law and the Punishment of War Crimes" (1980) 28 Chitty's L.J. 249.

26. Schedule, s. 2 (f).

27. U.S. v. Calley (1969/71; 1973) 46 C.M.R. 742, 48 C.M.R. 19, 1 Mil. Law Reporter 2488; see also trial of Capt. Smith, R.A.M.C. The Times (London) 8, 10, 12, 14, Apr., 28, 29 May, 1, 17 June, 1948; see also U.S. v. Wirz (The Andersonville Trial) (1865) H.R. Exec., Doc. No. 23, 40th Cong. 2d Sess., 1867-8, vol. 8. See also Israel: trial of Sgt. Major Salah Salah et al, Globe and Mail, 18 Feb. 1983.

28. Nuremberg Charter, Schindler and Toman, supra n. 22 at 689; Tokyo - U.S. Dept. of State Publ. 2671, Far Eastern Ser. 17, "Occupation of Japan, Policy and Progress', App. 32.

29. Res. $95(\mathrm{I}), 1946$. 
Since the Tokyo and Nuremberg Trials the law of armed conflict has embodied certain offences as treaty-created. In the Geneva Conventions of $1949^{30}$ and Protocol I Additional thereto, ${ }^{31}$ certain offences are described as 'grave breaches'. While no special tribunal is envisaged for their trial, the parties to these agreements: ${ }^{32}$

undertake to enact any legislation necessary to provide effective penal sanctions for persons committing, or ordering to be committed, any of the grave breaches of the Convention defined [therein, and] shall be under the obligation to search for persons alleged to have committed, or to have ordered to be committed, such grave breaches, and shall bring such persons, regardless of their nationality, before its own courts.

Here we have a clear recognition of the principle of universality which international law recognized in the case of pirates, but not of slave traders, although it is also provided that if any party affected prefers, "it may . . . in accordance with the provisions of its own legislation" hand such persons over for trial to another party to the treaties making out a prima facie case. Thus, while there is an obligation to seek out such persons, there is no obligation to amend national law in order to give effect to that part of international criminal law which authorises the trial of non-national war criminals.

International law is more concerned with the law of peace than it is with the law of war, and it recognizes that there is a general desire to see the rule of law upheld and breaches punished. This has led not to the creation of an international criminal law per se, but to what might be regarded as a substitute therefor. In order to prevent the possibility of criminals evading punishment by departing from a country which would have grounds to exercise criminal jurisdiction, states have (since the middle of the nineteenth century) entered into extradition treaties ${ }^{33}$, originally on a bilateral basis, but more recently on a multilateral basis. Put simply, the procedure has been to list a number of offences in the treaty for which the parties would return, on a reciprocal basis, fugitives alleged to have committed such offences. In order to ensure compliance with this treaty requirement, most countries have enacted legislation instructing their courts to authorise the extradition of those against whom evidence exists that they have in fact committed any of the crimes listed in the treaty. However, governments claim the right to deny extradition even if authorized by the courts, for whatever reason they deem proper. In addition, extradition does not apply to those accused of political offences, defined in the English-speaking world as crimes committed as part of and incidental to an organized attempt by an organized political movement to overthrow

30. Conv. I (Wounded and Sick in Warfare on Land), II (Wounded, Sick and Shipwrecked); III (Ps. W.), IV (Civilians), Schindler and Toman, supra n. 22 at 295-478, ratified by Canada in 1965.

31. (1977) 16 Int'l Legal Materials 1391 , not ratified by any member of NATO or the Warsaw Pact.

32. Geneva I, Art. 49, II 50, III 129, IV 146; since Pr. I is 'Additional' to the Conventions, it only extends the list of breaches and provides for their repression by way of requiring criminal proceedings.

33. See, e.g., Clarke, Law of Extradition (1903); Moore, Treaties on Extradition and Interstate Rendition (1891); Piggott, Extradition (1910); Shearer, Extradition in International Law (1971); Bassiouni, International Extradition and World Public Order (1974); La Forest, Extradition To and From Canada (1977); Booth, British Extradition Law and Procedure (1980). 
a government and seize power for itself $^{34}$ - hardly a satisfactory definition in this day of one-party states ${ }^{35}$ and efforts to express one's political views in a violent fashion ${ }^{36}$. In addition, most countries deny extradition for military offences, thus providing sanctuary for deserters and draft dodgers, though not necessarily for war criminals ${ }^{37}$. Extradition is also normally denied for revenue offences, so that in January, 1983, the director of a Norwegian oil construction company charged with defrauding the Norwegian government of about one and a half million dollars was released by the Bow Street magistrate, and so long as he stays in England he is safe from Norwegian criminal process ${ }^{38}$. It is clear, therefore, that though extradition is usually regarded as an example of international criminal law in practice, the loopholes are such that would not be tolerated in any system of national criminal law.

The issue which probably stirs most interest in international criminal law today is terrorism. But the issue is not new ${ }^{39}$, and it is, in fact, the offence which most nearly led to the creation of a proper system of international criminal law. After the assassination of King Alexander of Yugoslavia and M. Barthou, Foreign Minister of France, at Marseilles in 1934, the League of Nations drew up a Convention for the Prevention and Punishment of Terrorism ${ }^{40}$, and some of the members signed a further Convention for the Creation of an International Criminal Court ${ }^{41}$ which was intended to exercise jurisdiction over "persons accused of an offence dealt with in the Convention for the Prevention and Punishment of Terrorism". The Terrorism Convention, however, in forty-five years has been ratified only by the Empire of India; that is to say, by authority of a British Cabinet Minister for an overseas territory, even though the British Cabinet did not ratify on behalf of Great Britain. The Convention calling for the establishment of an international criminal court has not received a single ratification. It is true that the significance of these two Conventions was overshadowed by the Second World War and the war crimes trials that followed, but their fate is a sad commentary on the attitude of states in so far as international criminal law and its enforcement are concerned.

After the war crimes trials had ended, the issue of international criminal law tended to fade into the background, although there were

34. See, e.g., Re Castioni [1891] 1 Q.B. 149; Re Meunier [1894] 2 Q.B. 415; Re Schtraks [1964] A.C. 556; Cheng v. Governor, Pentonville Prison [1973] A.C. 931; Re Federenko (1910) 17 C.C.C. 268; Re State of Wisconsin and Armstrong (1972) 28 D.L.R. (3d) 513; Re Commonwealth of Puerto Rico and Hernandez (1972) 30 D.L.R. (3d) 260; Re Ezeta (1957) 62 F. 2d 198; Green, "The Nature of Political Offences" (1965) 7 Journal of Indian Law Institute 1, and supra n. 1 at Ch. VIII - 'The Right of Asylum in International Law.'

35. See, e.g., R. v. Governor, Brixton Prison, ex p. Kolczynski [1955] 1 Q.B. 540.

36. Re Shields(Ireland) The Times (London) 7 Dec. 1973 and McGlinchey v. Wren (Supreme Ct., Ireland) Case 149/82, judgment of 7 Dec. 1982; Re Giovanni Gatti (1947-France) 14 Ann. Dig. 145; Re Campara (1957-Chile) 24 I.L.R. 518; Re Kavic, Bjelanovic and Arsenijevic (1952-Switzerland) 19 I.L.R. 371.

37. See, e.g., The State (Ghana) v. Director of Prisons, ex p. Schumann (1966) 39 I.L.R. 433; Green, "Political Offences, War Crimes and Extradition" (1962) 11 I.C.L.Q. 329. See also, Federal Republic of Germany v. Rauca (1982) 38 O.R. (2d) 705 (Ont. S.C.).

38. Re Wagley, The Times, (London), 6 Jan. 1983.

39. See, e.g., Benjamin, The St. Alban's Raiders (1865) and 6 Brit. Dig. Int'l Law 651.

40. (1937) 7 Hudson, International Legislation 862.

41. Id. at 878 . 
still writers who felt that it warranted consideration ${ }^{42}$. However, it was not until such organizations as the Palestine Liberation Organization initiated its series of international aerial hijackings ${ }^{43}$ that the matter of terrorism again became one of intergovernmental concern. Three Conventions were drawn up under the auspices of the International Civil Aviation Organization between 1963 and $1971^{44}$ directed at acts of violence against aircraft, including hijacking. The net result of these Conventions was to provide for the trial by any state in whose territory an alleged offender was found or, failing that, for his extradition to a country with a prima facie case - aut punire aut dedere. The parties to these Conventions undertook to regard hijacking as an extraditable offence, even though it was not listed in any treaty or legislation. Moreover, it was contended that such offences could not be considered as political, but since the matter was to be adjudicated by the local courts in accordance with their habitual practice this is really a somewhat empty proviso. Moreover, it could hardly be considered a contribution to the suppression of aerial hijacking when the International Civil Aviation organization decided to grant observer status to the P.L.O., which had been responsible for the majority of the most notorious international hijacks.

The General Assembly of the United Nations considered it necessary to condemn terrorism against international aviation and as early as 1963 called for international cooperation to this end ${ }^{45}$. Since then, however, the United Nations' attitude to terrorism in its various manifestations has become increasingly politicized ${ }^{46}$ and its condemnatory Resolutions $\mathrm{s}^{47}$ are all rendered virtually nugatory by the incessant reference in such Resolutions to "the inalienable right to self-determination and independence . . . in particular the struggle of national liberation movements", a reservation which opens the door to any state classifying a terrorist movement as one of national liberation and enabling states to argue that the causes of terrorism must be eradicated even before any convention criminalizing terrorism can be adopted. This concern for one's political friends has even found its way into the efforts of the United Nations to prevent and punish acts of violence directed against internationally protected persons, including diplomats ${ }^{48}-$ although the value of this Convention was reduced somewhat by the Iranian seizure of the United States' embassy in Tehran and the inability of the United

42. See, e.g., Schwarzenberger, "The Problem of an International Criminal Law" (1950) 3 Current Legal Problems 263; Mueller and Wise, ed., International Criminal Law (1965); Bassiouni and Nanda, ed., A Treatise on International Criminal Law (1973).

43. See, e.g., McWhinney, ed., Aerial Piracy and International Law (1971); McWhinney, The Illegal Diversion of Aircraft and International Law (1975); Joyner, Aerial Hijacking as an International Crime (1974); Sundberg, "Lawful and Unlawful Seizure of Aircraft" (1977) 1 Terrorism 423.

44. Tokyo, (1963) 2 I.L.M. 1042; The Hague, (1970) 10 I.L.M. 133; Montreal, (1971) I.L.M. 1151.

45. See, e.g., Res. 2551 (XXIV), (1969).

46. See Green, "Double Standards in the United Nations: The Legalization of Terrorism" (1979) 18 Archiv des Volkerrechts 129. The text of the 1980 Resolution condemning terrorism, G.A. 34/145, is even more emphatic in this respect.

47. See, e.g., Res. 3034 (XXVII) (1973).

48. Convention on the Prevention and Punishment of Crimes Against Internationally Protected Persons, Including Diplomats (1973) Res. 3166 (XXVIII) Annex. 
Nations ${ }^{49}$ or the World Court ${ }^{50}$ to deal with it. While the Convention itself is silent on this matter, the Resolution of the General Assembly to which it is annexed provides that the "convention could not in any way prejudice the exercise of the legitimate right to self-determination and independence . . . by peoples struggling against colonialism, alien domination, foreign occupation, racial discrimination and apartheid." As if to confirm the legitimacy of this declaration of open season for terrorism against diplomats, the Resolution also provides that it "shall always be published together with the Convention", to whose provisions it is "related."

It is clear, therefore, that the United Nations as presently constituted is no more willing to see the development of a proper international criminal law with a court to adjudicate thereon than was the League of Nations. We are left, therefore, as we have always been, with international law defining the type of offences that states may, if they will, punish regardless of the nationality of offender or victim or locus of the offence. And the practice of courts in this regard is by no means consistent and frequently reflects the political attitude of the government of the country of which they are the judicial $\operatorname{arm}^{51}$. Perhaps this is most clear from the decision of the Quebec court which tried the kidnappers of the English diplomat James Cross after they had returned from their self-imposed exile ${ }^{52}$. Judge Mayrand conceded that kidnapping was an odious offence rendered the more serious in this instance since the victim was a diplomat, and "it is essential that the international partners of Canada know that their diplomats in residence are adequately protected and that the kidnappers of diplomats are adequately punished ${ }^{53}$. Acts of terrorism are crimes against humanity ${ }^{54}$ and strike a blow against the rights of man and against fundamental liberties, and when they are committed against diplomatic persons, bring harm to relations between States. Faced with such a situation, subjective considerations become secondary, and the inconveniences which imprisonment involves for the accused necessarily pale into insignificance." Having pointed out that the normal penalty for this type of offence might well be ten years imprisonment and that the lapse of time - nine years - was irrelevant, he commented upon the length of the accused's absence abroad and the impact that a severe sentence might have, particularly as the accused had repented and were now law-abiding. It would seem that popular feeling in Quebec was more important than upholding the rule of national and international law. The accused were sentenced to two years less a day.

49. See, e.g., Green, "The Tehran Embassy Incident and International Law" (1980) 38 Behind The Headlines; "The Tehran Embassy Incident - Legal Aspects" (1980) 19 Archiv des Volkerrechts 1.

50. Case Concerning United States Diplomatic and Consular Staff in Tehran [1979] I.C.J. 7, [1980] I.C.J. 3.

51. See, e.g., Green, "Terrorism and the Courts" (1981) 11 Man. L.J. 333.

52. R. v. Cossette-Trudel (1979) 52 C.C.C. (2d) 352362.

53. Canada ratified the Convention on Crimes against Internationally Protected Persons in 1976.

54. The original French text of the judgment, 11 C.R. (3d) 1, uses the term 'lèse-humanitè" at 14 . 
Despite the frustrations that one must feel at the unlikelihood of the development of an effective international criminal law, there are still efforts being made to draft a code and to create a tribunal ${ }^{55}$. Moreover, the International Law Commission of the United Nations which, for a number of years concerned itself with the drafting of a Code of Offences against the Peace and Security of Mankind ${ }^{56}$, has now decided to embody a statement on international crimes in its draft on state responsibility, and thirty five articles to this effect have been adopted ${ }^{57}$. The principles adopted by the Commission are far more reflective of current political ideology, particularly as understood by the states of the third world and their sympathisers everywhere, than they are of criminal jurisprudence. Article 19 of the draft states:

on the basis of the rules of international law in force, an international crime may result, inter alia, from: (a) a serious breach of an international obligation of essential importance for the maintenance of international peace and security, such as that prohibiting aggression; (b) a serious breach of an international obligation for safeguarding the right of self-determination of peoples, such as that prohibiting the establishment or maintenance by force of colonial domina. tion lit would be interesting to know whether it was the Argentine invasion of the Falklands or the British repulsion of this which would fall under the condemnation of this provision]; (c) a serious breach on a widespread scale of an international obligation of essential importance for safeguarding the human being, such as those prohibiting slavery, genocide and apartheid [it is important to note that the Convention ${ }^{58}$ which describes apartheid as a crime against humanity has been ratified by only a third of the members of the United Nations and not by a single western democratic statel; (d) a serious breach of an international obligation of essential importance for the safeguarding and preservation of the human environment, such as those prohibiting massive pollution of the atmosphere or of the seas.

It is perhaps unfortunate that, as yet, there is no international treaty creating such an obligation. In addition to these highly political crimes, the draft provides that "an internationally wrongful act which results from the breach by a State of an international obligation so essential for the protection of fundamental interests of the international community that its breach is recognized as a crime by that community as a whole, constitutes an international crime." Such a definition which envisages popularly-held conceptions of criminality expressive presumably of the volksgeist, has not figured in any national system of criminal law since the Nazi conception of crimes based on "sound popular sentiment" which has been reintroduced, perhaps in less objectionable terms, in the Constitution of the Polish People's Republic ${ }^{60}$, which provides that the Prosecutor General "safeguards the people's rule of law [while] the Courts are the custodians of the political and social system of the Polish People's Republic; they protect the achievements of the Polish working people, safeguard the people's rule of law, social property and the rights of citizens."

If one examines the draft that has been adopted by the International Law Commission and does so with an analytical and critical eye ${ }^{61}$, one is

55. See, e.g., Bassiouni, International Criminal Law (1980); Green, "An International Criminal Code - Now?" (1976) 3 Dal. L.J. 560.

56. (1954) II Y.B.I.L.C. 149.

57. Arts. 1-32, (1979) II Y.B.I.L.C. 91-93; Arts. 33-35, (1980) II Y.B.I.L.C. Part 2, 34, 52, 61.

58. (1973) G.A. Res. 3068 (XXVIII) Annex.

59. Jones, The Nazi Conception of Law (1939) 30.

60. 1952, as amended, Arts. 58, 64; 13 Blaustein and Flanz, Constitutions of the Countries of the World (1982) 15.

61. For a critical analysis of the draft, see Green, "New Trends in International Criminal Law" (1981) 11 Israel Y.B. on Human Rights 9. 
reminded of Article 38 of the Statute of the International Court of Justice. By paragraph (c), the Court is instructed to apply as law "the general principles of law recognised by civilized nations." No guidance is given, however, as to what those general principles are or how one measures civilisation. In fact, all this seems to mean is "those principles of law which are generally recognized by oneself and those that one considers to be civilized." So will any single state decide which are "the fundamental interests of the international community [the] breach [of which] is recognized as a crime by that community as a whole."

In the light of all this, one can only conclude that, despite all the talk about an international criminal law, the prospects of anything real or similar to a criminal code of the kind that exists within the nation are minimal. The type of proposal being considered by the International Law Commission, even if it materialises into a formal Convention, is likely to fail for want of ratifications. If it does come into existence it will do so only for that handful of members of the United Nations that will subscribe to any 'motherhood' document which they have absolutely no intention of carrying out in practice. It will, however, serve them as a means for criticising the non-signatories, primarily likely to be the western democracies, even though the latter are far more likely to give effect in their national criminal systems to those principles that international law has over generations condemned as criminal, or which those who believe in the international rule of law regard as essential for any proper international legal system to operate. Thus, the United Kingdom has already introduced a bill in the House of Commons to give effect to the 1980 Convention on the Physical Protection of Nuclear Material. ${ }^{62}$ By the Nuclear Material (Offences) Bill ${ }^{63}$, any act of terrorism involving nuclear material or a nuclear threat will be punishable in the United Kingdom, or its offender rendered extraditable, regardless of the nationality of the offender or the place of his offence or of the potential victim. It will be interesting to note how many other countries, particularly those sympathetic to so-called liberation movements will introduce similar legislation.

If there is to be any hope for the development of anything in the nature of an international criminal law, we should recognize the cleavages, ideological and otherwise, that exist in the modern world, particularly in so far as developing countries are concerned. ${ }^{64}$ This might well mean that we abandon any hope for a universal international criminal law. Prospects for the future may lie in the development of regional systems; for example, the European countries, the English-speaking world, the Latin American nations (which already speak of their own system of international law) ${ }^{65}$, the Soviet bloc ${ }^{66}$, and Africa and Asia (with their own Asian-African Consultative Legal Committee). Each of these may develop its own views of international criminality and justiciability, recognizing that there may be overlaps in groupings and in conceptions. From such regionalism, a more widely based concept of an international criminal law may in fact develop. ${ }^{67}$

62. 18 I.L.M. 1419.

63. The Times (London), 22 Jan. 1983.

64. See, e.g., supra n. 1 at Ch. V - "The Impact of the New States on International Law".

65. See, e.g., Asylum Case [1950] I.C.J. 266.

66. See, e.g., Tunkin, Theory of International Law (1974) especially re the 'Brezhnev Doctrine' at 440.

67. See Green, supra n. 55 at 578-579. 